\title{
密集市街地における内水氾濫時の 歩行避難および車両移動の危険度評価 DIFFICULTY IN WALKING AND DRIVING DURING PLUVIAL FLOOD IN DENSE URBAN AREA
}

\author{
浅野統弘 1 ・尾㟝平 2 ・石垣泰輔 3 ・ 戸田圭一 4 \\ Norihiro ASANO, Taira OZAKI, Taisuke ISHIGAKI, Keiichi TODA

\begin{abstract}
1学生会員 関西大学大学院 理工学研究科（†564-8680 吹田市山手町3-3-35）
2正会員 博(工) 関西大学助教 環境都市工学部 都市システム工学科（テ 564-8680 吹田市山手町3-3-35）

3 正会員 博(工) 関西大学教授 環境都市工学部 都市システム工学科（テ 564-8680 吹田市山手町3-3-35）
\end{abstract} \\ 4正会員 Ph.D. 京都大学大学院教授 工学研究科社会基盤工学専攻（干615-8540 京都市西京区京都大学桂）
}

\begin{abstract}
Torrential rainfalls over $50 \mathrm{~mm} / \mathrm{h}$ have been observed frequently in recent year and these rainfalls caused pluvial and fluvial floods in urban and rural areas. Evacuation of elderly person and traffic difficulties during pluvial flood in urban area are investigated here. As the inundation occurs in a short time, people have to evacuate through inundated road and avoid the traffic difficulties on their evacuation route. In this paper, this problem is discussed by using a commercial model, InfoWroks CS, of which accuracy is verified with the survey data of Osaka flood on 27, August, 2011. From the results, it can be shown the maps of walking and driving difficulties for pluvial flood.
\end{abstract}

Key Words : urban flooding, short-time rainfall, evacuation, walking and driving difficulties

\section{1. 緒論}

近年，地球規模の気候変動の影響により，局所的な集 中豪雨が増加している. 都市部では下水道の流下能力を 上回る集中豪雨により, 内水氾濫が発生する事例が散見 される. 都市機能の集積地区や住宅密集地区において水 害が発生した場合，浸水による直接的な被害だけでなく， 交通機能障害や営業停止等の間接被害が生じる.

近年では2011年8月に東京，大阪の中心部において内 水汇濫が発生し，道路冠水による一部通行止めやビル地 下の店舗の浸水による浸水被害が発生しており，その対 策が急務となっている. 内水汇濫特性について筆者ら ${ }^{1)}$ は被害についてヒアリング調査を行い，実際に生じた水 害時の対応行動からみた水害時の脆弱要因について考察 を行っている. また, 既往研究において都市部の交通障 害について，深草ら ${ }^{2)}$ は，内水汇濫時の京都市域の道路 交通障害予測を行い，内水汇濫時に市中で混雑する道路 が増える様子を解析モデルにより表現し，車両の移動時 間が増加すること, 豪雨発生の時間帯によって交通障害 の程度が変化することを明らかにしている．戸田ら ${ }^{3)}$ は，
車模型を用いた水理実験の結果をもとに，都市部におけ る洪水汇濫時に，どの程度の流れの状態で車が流される か，またその後どのような漂流速度で流されるかの検討 を行っている.

また，大都市部における脆弱箇所の一つであり，多く の人々が集まる地下街への影響について, 井上ら ${ }^{4)}$ は内 水汇濫時における大規模地下街の浸水過程と避難の安全 性に関する検討を行っている。関根ら ${ }^{5)}$ は，地下空間浸 水時の避難行動の予測について人を個別に取り扱える独 自で開発したモデルを用いた地下空間浸水時の避難行動 シミュレーションモデルの研究が進められている.

また, これらの推定に不可欠な都市域の内水汇濫解析 に関する既往の研究では，関根 ${ }^{6}$ による住宅密集地を対 象とした数值解析, 武田・松尾 ${ }^{7)}$ による下水道解析を考 慮したネスティングモデルに関する研究，川池ら ${ }^{8)}$ の雨 水排水設備も考慮した氾濫模型実験との比較によるモデ ルの検証等が行われている.

本研究では, 既往研究1)での再現計算にて, 一部不十 分であった再現性の問題点を改善し，再検証をした.さ らに，その計算モデルを用いて，近年で最も降雨量を観 測した「平成20年8月末豪雨」を外力とし，対象地域内 
の密集市街地である大阪の梅田周辺の汇濫計算を行い, 内水汇濫時の地下空間への汇濫水一の流入と地上におけ る人の避難困難度と車両の移動困難度について考察した。 本研究の特徵は, 解析モデルによる内水汇濫現象の再 現性を向上させ，筆者らがこれまで害施してきた実物大 模型実験で得られた高齢者を含む浸水時避難の困難度指 標を用いて地上の部の避難困難度指標を示し, 考察して いること，さらに既往研究において，交通障害に関する 検討は行ったものの, その後の水害時の車両の移動や漂 流に関する実験の知見を考慮した移動困難度を用いて考 察していることである.

なお，地上部分の避難については高齢者女性を対象に 安全避難を検討した。 これは高齢者女性が浸水時の避難 困難度が高く，高齢者女性が安全に避難できれば，大多 数の人が安全に避難できると考えたためである.

\section{2. 対象地域の概要}

対象地域は，大阪市北区と福島区の下水処理(污水処 理と雨水排除)を担っている海老江処理区である(1,215ha). この処理区は内に，終末処理場が1箇所，中継ポンプ場 が3箇所存在する.

大阪市北区(梅田周辺)は，昼夜問わず老若男女が集ま り，百貨店・オフィスビル・ショッピングモール・ホテ ルなどが立ち並んでいる。主要道路の地下には地下街も ある.これらの地下街は, 公的な地下街出入口だけでも 129箇所あり，隣接ビルや地下ショッピング街などと結 合し，一つの大きな地下街を形成している．交通機関は， $\mathrm{JR} \cdot$ 私鉄・地下鉄の7つの地上・地下駅があり, 交通の 要衝といえる. また, 交通量の多い幹線道路も多数ある.

\section{3．実績豪雨による氾濫計算とモデルの検証}

\section{（1）数值計算モデル}

本研究では, 下水道ネットワークと地上の氾濫水を同 時に計算できるInfoWorks CS(以下，IWCS)を用いた ${ }^{9), 10)}$ モデルは, 有効降雨モデル, 地表面流出モデル, 管内水 理モデル，地表面氾濫計算モデルから構成されている.

観測された降雨をインプットデータとし, 各地表面(道 路, 屋根, 浸透域)に応じて, 有効降雨を算定し, 単一 貯留地モデルより地表面流出量を算定する. 地表面流出 量が管内水理モデルのインプットデータとなり，管渠内 水理は, サン・ブナン式(圧力時はプライスマンのス ロットモデル)により計算される，地表面氾濫計算は, 非構造格子による2次元不定流解析(浅水流方程式)である. マンホールからの格子への溢水量および格子からマン ホールへの流入量は，堰の公式を用いており，地表面氾 濫計算と管内水理解析は連動している. また, 地下街出
入口の考慮方法は, 地下街出入口に仮想の堰を設けた. よって, 地下街出入口付近の道路における浸水深が堰高 を超えると地下街へ流入する. 本研究では梅田周辺部の 公的な出入口129箇所を対象とした(接続ビル等の出入口 は未考慮).また，地盤高データは，航空レーザー測量 による地盤高データではなく, マンホールの地盤高デー タを用いた，理由は，マンホールの地盤高が現地での測 量に基づくものであり, 航空レーザー測量と同様に精度 の高い結果であると判断したためである.

\section{(2) 再現計算における計算モデルの改良・変更点}

既往研究1)では，2011年8月27日に大阪で発生した集中 豪雨による対象地域内の被害について再現計算を行い, 計算モデル(以下 ; 既往モデル)の検証を行っている. 既 往モデルは，GISを活用し，1/2500の基盤地図をべース に道路部と住区（街区）に分け，道路面のみを汇濫計算 の対象としていた. しかし, 道路面の中央分離帯や高架 橋道路の擁壁等を十分に考慮できていなかったため, 浸 水深の計算結果が現地調查の約半分の地点があった，そ のため既往モデルに, 擁壁や中央分離帯等の道路構造物 を考慮した.

また，既往モデルは，時間的な制約もあったことから， 2006年までに建設された管渠ネットワークを用いて氾濫 計算を行っていた. しかし，大阪市建設局への調査の結 果, 梅田周辺の再開発事業に伴い2006年以降に管渠が増 設されており, それらも考慮した。

さらに, 既往モデルでは, 対象地域内に一様の降雨形 態（分布）を与えていた. しかし，局所的な集中豪雨で は数 $\mathrm{km}$ 離れただけで降雨形態は恋化する. その降雨形 態の変化を考慮するため, 対象領域内に存在する3箇所 の雨量計の地点をもとに, 対象領域をボロノイ分割し, 各地の雨量データを用いた.

\section{（3）2011年8月27日の局地的な大雨の概要}

大阪管区気象台(大阪市中央区)では，16時 08 分までの 1 時間に $77.5 \mathrm{~mm}$ (観測史上 1 位タイ)を記録し，10分間降雨 量でも最大 $22.5 \mathrm{~mm}$ (観測史上2位)を記録している. 総降 雨量は88mm, 降雨継続時間は3時間20分であり, 短時間 に集中した降雨である. なお，対象地域における下水排 水能力は約 $60 \mathrm{~mm} / \mathrm{h}$ である.

この影響で, 大阪市などで, 床上浸水(87棟), 床下浸 水(234棟), 道路冠水(9箇所)等の浸水被害が発生してい る(29日11時現在:大阪府調べ).

\section{(4) 再現計算によるモデルの検証}

昨年実施したヒアリング調査 ${ }^{1}$ において，対象地域内 の消防署や梅田周辺にある店舗の従業員に, 道路冠水被 害が発生した場所, 時間帯, 浸水深などを調査した。こ こでの浸水深は，ヒアリング調査ならびに浸水痕跡から 推定される浸水深(以下: 実績浸水深)である. 調查によ 
り得られた道路冠水籄所と実績浸水深を図-1に示寸.

次に，計算モデルによる最大浸水深の結果を図-2に示 寸．図中の(1)〜 (3)地点の計算結果と実績浸水深の誤差は, 誤差土 $10 \mathrm{~cm}$ 程度であり，再現性は高いと判断できる。 図中の(4)地点は, 既往モデルにおいて汇濫水量が多く, 浸水深が高い地点であったが，モデルの改良により汇濫 水量が減少し，その再現性が向上した．また，図中の(5) 地点の既往モデルと本計算モデルの浸水深の計算結果を 図-3に示寸．既往モデルは，道路中央構造物を考慮して いなかったため，過小評価となっていた。道路中央構造 物を考慮することにより，実績浸水深と同等の結果が得 られた. 図-2の(6)地点も道路中央構造物を考慮したこと で，同様の結果が得られた．また，既往モデルでは，数 カ所の地下街出入口より汇濫水が流入する結果であった が，本モデルでは，地下街出入口からの流入はなく，地 下街管理者へのヒアリング調査で得られた流入実績なし と合致する結果となった。

以上の結果より，本モデルは，既往モデルよりも，高 い精度で計算できるようになったと判断できる.

\section{4. 内水氾濫計算}

\section{（1）都市部における内水汇濫災害}

2011年8月の豪雨では道路冠水や店舗内に氾濫水が浸 水するなどの被害はあったが，地下街への汇濫水の流入 や人々の命に危険を及ぼすような被害はなかった。

しかしながら，同豪雨よりも多い豪雨が降った場合， 地下街一の汇濫水の流入等に伴う内水災害が発生寸る可 能性がある，そのため，本章では，近年で最も短時間に 降雨量を記録した愛知県岡崎市美合町で観測された「平 成20年8月末豪雨」の降雨データを用いて汇濫計算を行 い，3対象地域における内水汇濫災害の被害想定を行っ た.

\section{（2）内水汇濫計算の結果と考察}

計算対象である道路面の全体面積は約324haである. 本計算結果の最大浸水面積は約252haであり，計算対象 地域の約 $80 \%$ 範囲が浸水する結果となった. また，マ ンホールからの溢水量は約 600 万的 3 であった.

図-4に梅田周辺の最大浸水深の結果を示寸．図のよう に, 梅田周辺は $90 \%$ 以上が浸水する. また, 梅田周辺の 北側は浸水深が $1 \mathrm{~m}$ 以上であり，危険なエリアであるこ とがわかった．このエリアは，ショッピングモールや飲 食店などが立ち並び，昼夜問わず人通りや交通量が多い， 集中豪雨が降った場合，迅速な交通規制や避難アナウン スなどの対応が必要である.

図-5に汇濫水が流入した地下街出入口を示寸. 浸水し た出入口は50箇所であり, 総流入量は約 $21 万 \mathrm{~m}^{3}$ である. また，図のように浸水した地下街出入口をArea A〜Area Fの6ブロックに区別した. エリア別に区分した流入量の

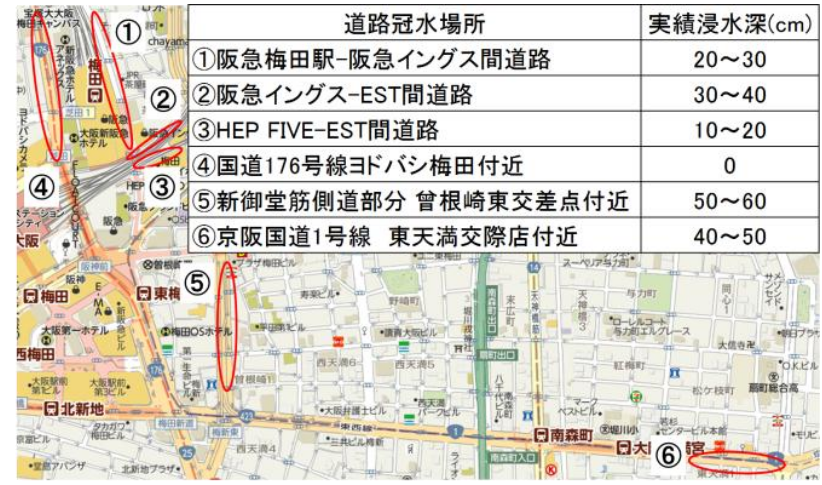

図-1 現地調査による道路冠水箇所と浸水深

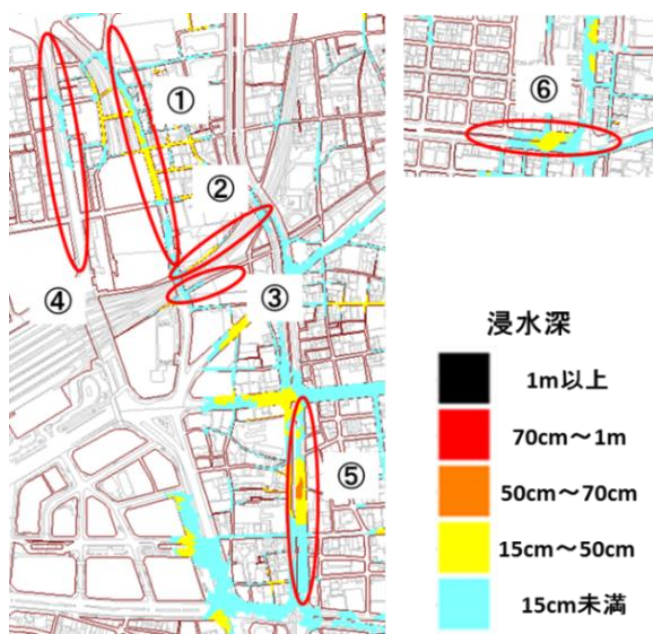

図-2＼cjkstart再現計算による最大浸水深結果

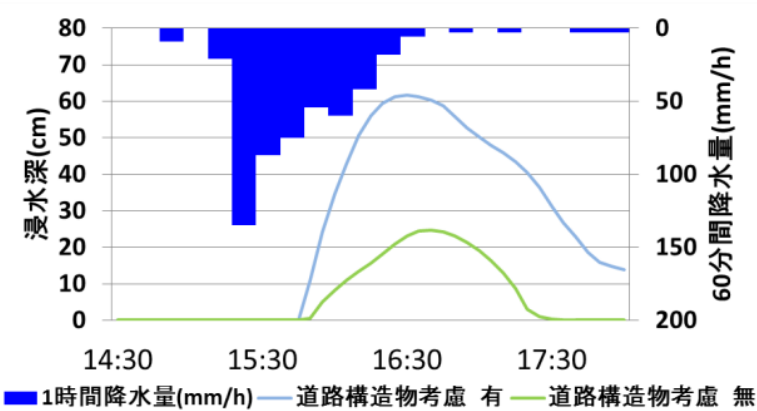

図-3＼cjkstart道路構造物考慮における浸水深の変化

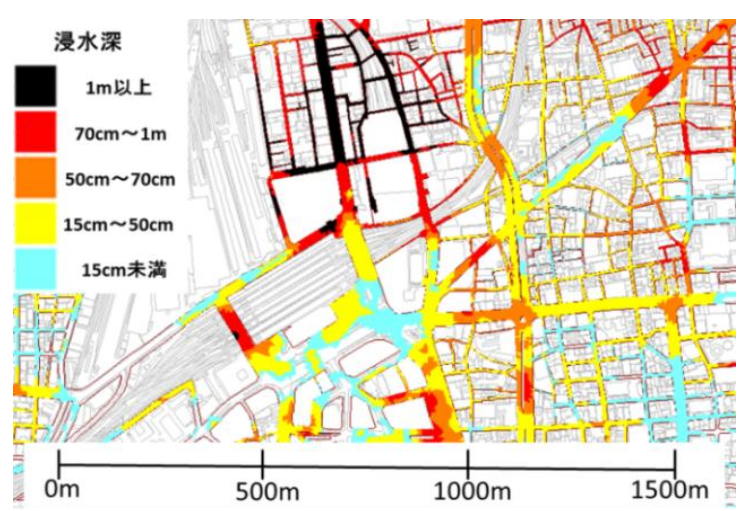

図-4＼cjkstart梅田周辺における最大浸水深結果 
時間変化のグラフを図-6に示す. 地上部の浸水深が $1 \mathrm{~m}$ を超える地点が存在するArea AとArea Bの地下街への ピーク流入量は約 $15 \mathrm{~m}^{3} / \mathrm{s}$ であり，発生時間は，降雨量 ピークの約 1 時間後に迎えることが知れた。 これらより， 地下街へ浸水が始まる前に迅速な対策を施さなければな らない. 地下街への流入開始時間は, 降雨開始から約 1 時間後である.わずか1時間で，地下街管理会社は地下 街出入口への浸水対策(止水板の設置など)や地下街利用 者への避難誘導などを実施しなければならない. 甚大な 被害にならないように，防災・減災対策を日頃から強化 して，避難計画を策定しておくべきである.

\section{5. 高齢者女性の安全避難}

\section{（1）歩行避難度評価}

a) 単位幅比力

検討条件として, 本研究では避難困難度指標として単 位幅比力を用いる. 単位幅比力 $\left(\mathrm{m}^{3} / \mathrm{m}\right)$ とは流れの単位 幅あたりの力の大きさであり，式(1)に示すように単位 幅に作用する運動量と水圧の和を単位体積重量で除した 值で示される。

$$
M_{0}=\frac{u^{2} h}{g}+\frac{h^{2}}{2}
$$

浅井ら ${ }^{11)}$ の研究より, 単位幅比力を用いて避難困難状 態を示すことは可能であり，属性ごとに得られている值 を表-1に示す．表より，高龄女性が一番低い值を示して いる. 全員が安全に避難する必要があることを踏まえ, 高齢女性の単位幅比力の值を評価基準とした.

\section{b) 最大単位幅比力の状況}

図-7に梅田周辺の最大単位幅比力の状況と大規模地下 街出入口の位置を示す. 図に示したように，浸水深が $1 \mathrm{~m}$ を大幅に超える梅田北側では避難限界状態な場所が 多く占めている. 大規模地下街から避難する場合, 地上 の氾濫状況によっては出入口からからの避難できない可 能性がある.

大阪市北区は避難所としては，小学校などの公共施設 を指定している. しかし，梅田のような人の出入りが多 い繁華街では，行政が指定した避難所を知らない人も多 いと考えられる，また，降雨開始から浸水が始まるまで は約1時間と限られており，避難所を探すよりも，浸水 被害が著しい場所では，高層ビルやショッピングモール 等の2階以上に避難するように誘導することが望ましい．

現状においてビル管理者の立場からするとセキュリ ティ上，2階以上を一時避難場所として活用することは 容易ではない。しかしながら，内水災害であっても想定 される事の重大さを認識し，多様なステークホルダーが 存在する市街地においても，連携を高め，地域としての

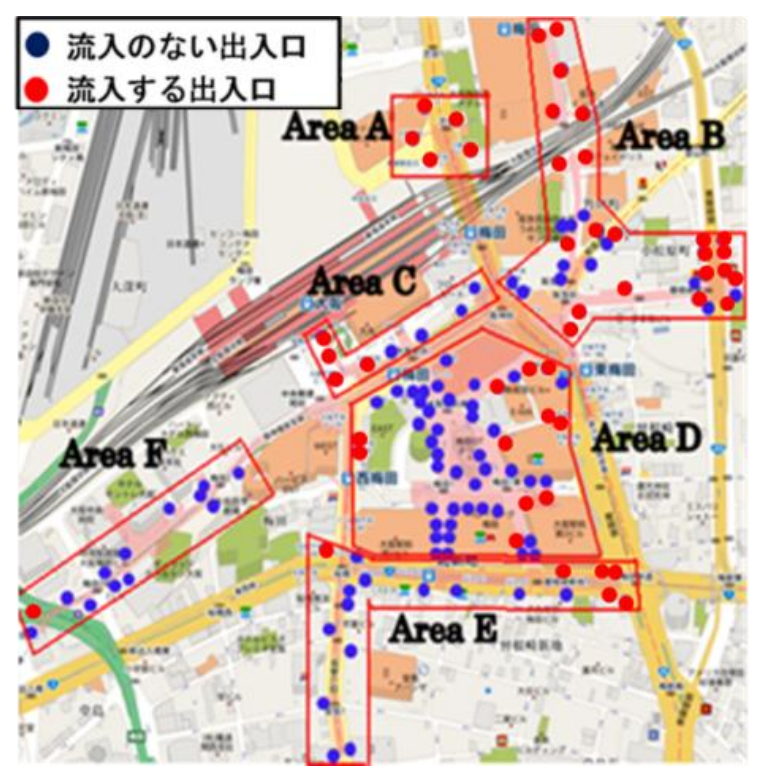

図-5 浸水した地下街出入口

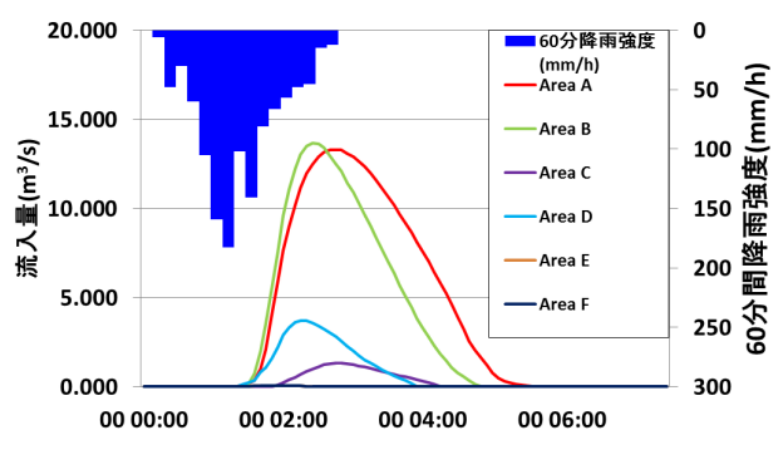

図-6 地下街出入口からの流入量

表-1 単位幅比力

\begin{tabular}{|c|c|c|}
\hline & 避難困難度状態 & 避難限界状態 \\
\hline 成人男性 & 0.125 & 0.250 \\
\hline 高齢男性 & 0.100 & 0.200 \\
\hline 成人女性 & 0.100 & 0.200 \\
\hline 高齢女性 & 0.080 & 0.160 \\
\hline
\end{tabular}

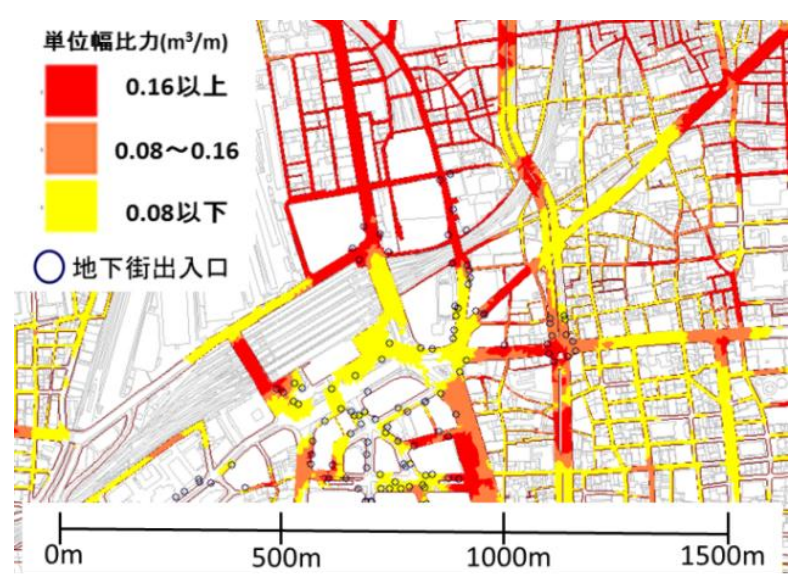

図-7＼cjkstart梅田周辺における最大単位幅比力の結果 
防災計画を策定していくことが重要である．本結果はそ のような協議をする場において活用されるものである.

\section{6. 内水氾濫に伴う交通障害と水没車からの避難}

交通規制に関して既往研究2)では短時間豪雨の発生時 間により道路交通障害の程度が異なることが結論付けら れている. しかし, 本研究対象地域は, 都市部の繁華街 ということもあり，昼夜問わず交通量が多い，そのこと から，「平成20年8月末豪雨」のような集中豪雨が発生 した場合における内水汇濫時には，車における甚大な被 害が想定できる．また，戸田ら ${ }^{3)} の$ 研究より，車の移動 限界条件と漂流限界を求める際の抗力係数の算出により, 汇濫水の流速 $2 \mathrm{~m} / \mathrm{s}$ 以上かつ浸水深が $0.5 \mathrm{~m}$ 以上の場合に車 は流される危険性が高い場所であることが示されている。 上述の研究では, 外水汇濫時の場合を想定し, それらの 条件を用いて考察を行っている.

本研究では，内水災害ということもあり汇濫水の流速 は $2 \mathrm{~m} / \mathrm{s}$ を超すような危険な場所は計算結果では得られな かった．浸水深においては，1mを超えるような場所は 存在し，車が流される条件である $0.5 \mathrm{~m}$ を超越し，車両に 浮力が働き, 汇濫水の流速 $2 \mathrm{~m} / \mathrm{s}$ 以下でも車が漂流寸る危 険性がある.

また，筆者らは，車100台を対象に車の後部に設置さ れているマフラーの地面からの高さについて調査を行っ た. その結果, マフラーは地面から平均約 $30 \mathrm{~cm}$ に設置 されていることが知れた。 それらより，浸水深が $30 \mathrm{~cm}$ を上回る浸水が発生した場合は，マフラーから水が逆流 し, 車の動力であるエンジンに水が流れ込み, エンジン トラブルによりエンジンが停止することが懸念される.

よって, 浸水深が30cm以上の場所は車のエンジンが停 止し，交通障害が発生する危険性が高い.

また，馬場ら ${ }^{12}$ は，水没した自動車からの避難に関す る実験研究において, 地上からの水深が75 80cmで, 水 圧のためにセダン型の小型車の運転席からの避難が困難 となることを示している.これは浸水が1mを超すよう な場所では, 安全に車から脱出することは極めて難しい ことを指摘している.

上記の実験，調查により得られた結果を基に自動車交 通の障害に関する指標として浸水深 $30 \mathrm{~cm}$ 以下， $30 \mathrm{~cm}$ $70 \mathrm{~cm}$ (エンジンが停止すると考えられる浸水深), $70 \mathrm{~cm}$ 以 上(車からの脱出困難となる浸水深)の3段階を設定した.

図-8に時間経過毎の結果を示す. 雨が降り始めてから1 時間30分が経過した頃から浸水深が $30 \mathrm{~cm}$ 以上を超える 場所が出てくる. 2 時間後には，浸水深が $70 \mathrm{~cm}$ 以上を超 える場所もある。また，梅田周辺においては，30 cm以 上の浸水深に達する場所が面積の約 $90 \%$ を占める.この 状態が約1時間継続し，3時間を過ぎたあたりから浸水深 が低くなり，浸水面積も狭まる，しかし，図のように梅

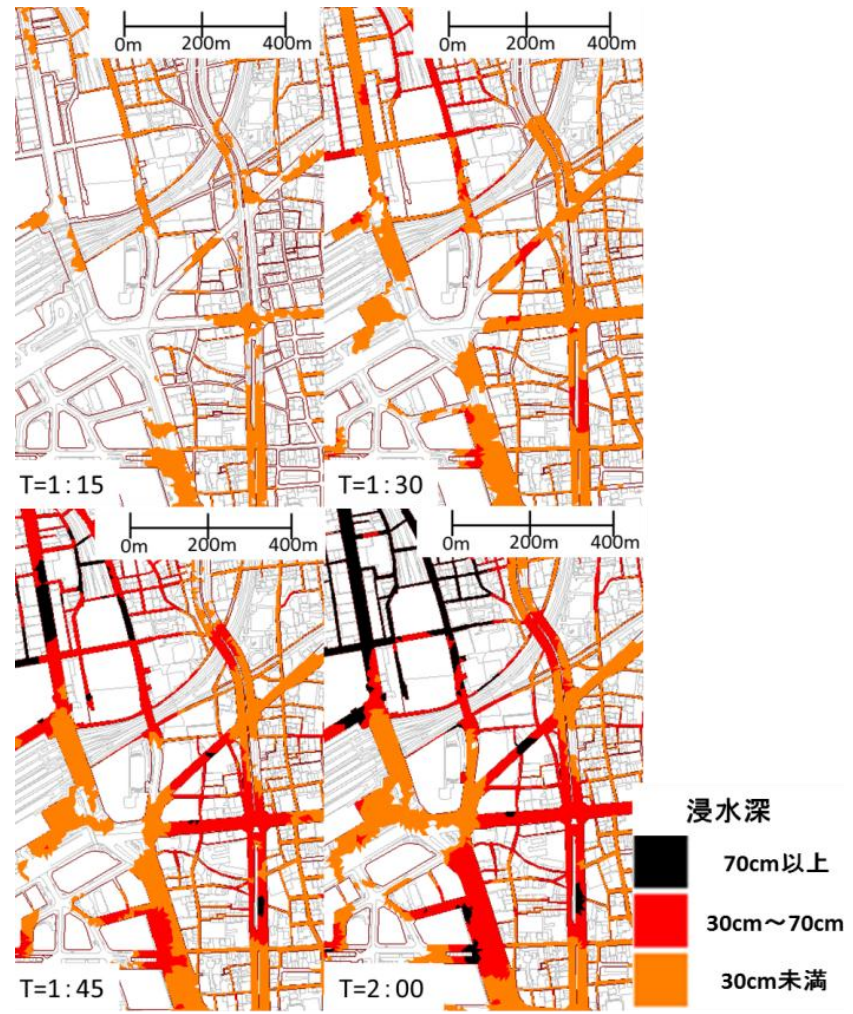

図-8 車両安全避難マップ

田周辺の北側においては, 浸水深が70 $\mathrm{cm}$ 超える場所 があり，これらの場所に関しては降雨開始から4時間 30 分まで続く，そして，5時間を過ぎたあたりで浸水深が $30 \mathrm{~cm}$ になり，6時間後には，道路冠水はほとんどの場所 でなくなる.

これらより，降雨開始から1時間を過ぎたあたりから マンホールから溢水し, 地上の浸水が始まる. また， 1 時間 30 分で浸水深が $30 \mathrm{~cm}$ 超える場所が拡がる. $30 \mathrm{~cm}$ の浸水が始まると車のエンジンが故障し車は停車する. また浸水深が70 cmを超える人々は車から脱出すること に限界を迎える，また，車に浮力が働き漂流する危険性 もある。これまでアンダーパス部などについては，交通 規制の対象地点として，警察等のホームページに記載さ れている. しかし，本計算結果からもわかるように，豪 雨時には車が停止する恐れのある浸水深 $(30 \mathrm{~cm}) を$ 超える 箇所は多数存在し, 寸り鉢状の地形を有する道路形状の 地点では, さらに深い浸水深となることが予見された. 短時間集中豪雨では，今回の例のように $30 \mathrm{~cm}$ 以上の浸 水が拡がるまでに要する時間は1時間15分程度と非常に 短い，このような短時間において，交通規制をかけるこ とは非常に困難であるが，本検討のような事前に危険と なる箇所を想定し, 特に幹線道路については, ぞの程度 の降雨により交通障害が発生するか否か，その場合はど のように対応するか, 事前に検討, 計画しておくことが 重要である.この場合も消防署・警察・道路管理者，下 水道管理者が一体となり, 協力して交通障害の未然防止 ならびに被害軽減のために協議しておくべきである. 


\section{7. おわりに}

本研究では, 既往研究1)において, 一部不十分であっ た2011年8月の大阪市内の集中豪雨による内水汇濫の再 現計算に対して，中央分離帯や道路擁壁の考慮，再開発 に伴い敷設された下水道管渠のモデルを反映，エリア別 の降雨データの使用改善を行い，再検証した．また，そ の計算モデルを用いて，近年で最も降雨量を観測した

「平成20年8月末豪雨」を用いて，対象地域における内 水氾濫被害について想定し, 高齢者女性における安全避 難と車両移動の困難性について考察を行った．本研究で 得られた主な結果を以下に示寸.

1) 計算モデルの改良を行うことにより，現地でのヒア リング調査に基づく実績浸水深，道路浸水箇所を精度よ く再現することが検証できた。このことより，既往モデ ルよりもモデルの高精度化が図れ，内水汇濫現象を精度 よく計算できるモデルが構築できた.

2)「平成20年8月末豪雨」を用いて汇濫計算を行った結 果, 対象地域である梅田周辺においては甚大な浸水被害 が生じることが明らかとなった．浸水深が $1 \mathrm{~m}$ を超える 場所もあり，また，大規模地下街一の流入箇所は全出入

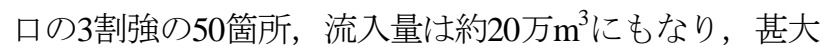
な被害を招くことが示唆された。 また，既往モデルで得 られた結果と同様に地下街出入口からの流入量のピーク は降雨量のピークから約1時間後であり，それを考慮し た地下空間における浸水対策，避難計画を策定する必要 がある。

3）高齢者女性における避難困難度指標である単位幅比 力を用いた避難の検討の結果, 内水汇濫であっても, 浸 水被害が甚大である梅田周辺においては, 避難困難・避 難限界状態が約4時間続くことが明らかとなった，その ため, 避難に対する対応方針を地下街管理会社, 鉄道事 業者, ビルオーナー, テナント事業者, 行政等の各ス テークホルダーが連携して策定することが不可欠である。

4) 自動車交通の障害に関する指標として浸水深 $30 \mathrm{~cm}$ 以 下，30 70cm(エンジンが停止すると考えられる浸水深), $70 \mathrm{~cm}$ 以上(車からの脱出が困難となる浸水深)の3段階を 設定し，考察をした，その結果，エンジンが停止する指 標である浸水深 $30 \mathrm{~cm}$ は高齢者女性の避難で得られた結 果と同様に，梅田周辺では約4時間以上続き危険である。 また梅田周辺は，交通量も多いため，車両の停止等によ る渋滞の発生により, 緊急車両の通行阻害や大きな経済 損失が見込まれることが示唆された.

これらの結果から，交通障害を新たな知見として加え， かつ, 密集市街地である梅田周辺は多くのステークホル ダーが存在することから, 単一事業者の計画ではなく, 梅田周辺全体をマネジメントして行くことが重要である ことを結論付ける. そして, 今後の課題としては, 内水 汇濫時の安全避難について検討を行っていく.
謝辞 : 本研究を遂行するにあたり, 下水道管渠網データ を提供していただいた大阪市建設局の関係各位に心から 謝意を表します，なお，本研究は日本学術振興会の科 研費 (24710053, 研究代表者: 尾㠃平) の助成を得て 行った研究の一部である.

\section{参考文献}

1）尾㠃平，石垣泰輔，戸田圭一：高密度商業地域における内 水氾濫の脆弱要因に関する考察, 土木学会論文集 B1 (水 工学), Vol68, NO.4, I_1009-I_1014, 2012.

2）深草新, 戸田圭一, 宇野伸宏 : 内水汇濫時の京都市域の道 路交通障害予測, 京都大学防災研究所年報, 第52号, 平成 21年6月，2009.

3） 戸田圭一, 石坦泰輔, 尾㠃平, 西田知洋, 高垣裕彦: 氾濫 時の車の漂流に関する水理実験，河川技術論文集第18巻， pp.499-504, 2012.

4）井上知美，川中龍児，石坦泰輔，尾㠃平，戸田圭一：内水 汇濫における大規模地下街の浸水過程と避難の安全性に関 する検討, Vol.56, pp.973-978, 2011.

5）関根正人：複雑な構造をもつ地下鉄駅構内の浸水過程と避 難誘導に関する数値解析, 水工学論文集, 第 54 巻, pp.907-912, 2010.

6）関根正人：住宅密集地域を抱える東京都心部を対象とした 集中豪雨による内水汇濫に関する数值解析, 土木学会論文 集B1(水工学), vol.67, No.2, p p 70-85, 2011.

7）武田誠, 松尾直規: 下水道解析を考慮したh-VA汇濫解析 モデルに関する検討，水工学論文集，Vol54，pp.895-900， 2010.

8）川池健司, 清水篤, 馬場康之, 中川一, 武田誠 : 下水道を 含めた氾濫模型実験による内水氾濫解析モデルの検証，水 工学論文集, Vol55, pp.985-990, 2011.

9）尾㠃平，森兼政行，石垣泰輔，戸田圭一：市街地外水汇濫 解析一の分布型解析モデルの適用性-模型実験と数值解析 結果の比較, 下水道協会誌論文集, Vol147, No.9, pp.93102, 2010.

10）尾㠃平，石垣泰輔，戸田圭一：低平地住宅密集地域におけ る内水氾濫の危険度評価に関寸る研究，水工学論文集, Vol.53, pp.823-828, 2009.

11）浅井良純，石垣泰輔，馬場康之，戸田圭一：高齢者を含め た地下空間浸水時における避難経路の安全性に関する研究, 水工学論文集, Vol.53, pp.859-864, 2009.

12）馬場康之，石坦泰輔，戸田圭一，中川一: 水没車した自動 車からの避難に関する実験的研究，水工学論文集，Vol.53， 土木学会工学委員会, pp.853-858, 2009.

(2012. 9. 30受付) 